\title{
Tertiary Rules
}

\author{
RALF MICHAELS
}

\subsection{Introduction}

The entanglement between legal orders is a topic that legal theory has, until very recently, widely ignored or marginalized. For a long time, legal theory happened in the singular: it was mostly a theory of law, not a theory of laws. The object was one law, not many - whether that one law was confined and contingent (as in legal positivism) or all-encompassing and universal (as in natural law). In such a singular theory of law, relations between legal orders are ignored because, by definition, a multitude of laws is not conceptualized. Or, at best, multiple laws are subsumed, somewhere, under one ultimate law.

Such a multitude of legal orders is a theme of legal pluralism, a conceptualization of law as plural that has been discussed not only in legal anthropology and sociology but also in legal theory. Here, entanglement is recognized, but it is often not sufficiently theorized. In legal sociology, the interrelation between legal orders is often conceptualized as interlegality, a rather vague concept that obfuscates more than it actually explains. ${ }^{1}$ In legal theory, attempts have been made to conceptualize entanglement, and some of these are discussed in this chapter. However, there is a wide disparity of views. Some discuss entanglement as a matter of social fact, others as a matter of legal ordering. Some discuss entanglement from a neutral perspective, others view it from the perspective of peculiar legal orders, some as both. Some authors discuss a plethora of mechanisms to reduce conflicts between legal orders, or to organize interactions, or the like. But it does not always become clear

Thanks for valuable suggestions to David Dyzenhaus, Nico Krisch, and Tomáš Morochovič.

1 B. de Sousa Santos, 'Law: A Map of Misreading - Toward a Postmodern Conception of Law' (1987) 14 Journal of Law and Society 279-302; J. Klabbers and G. Palombella (eds), The Challenge of Inter-Legality (Cambridge University Press, 2019). 
what holds these mechanisms together and what keeps them apart. What we lack is an overarching conceptualization of these mechanisms.

This chapter suggests that these mechanisms should be understood as a peculiar type of legal rules. These rules are different from primary rules because they do not provide commands, dos and don'ts. They are also different from secondary rules because they do not determine issues of validity and valid change of a legal system, at least not in the way in which we traditionally understand secondary rules. Instead, they are a different type of legal rules I propose to call tertiary rules. Tertiary rules are rules with which one legal order designates, relative to itself, the normative space of another legal order to which it is not hierarchically superior. In an earlier publication, I discussed a special case of these tertiary rules, namely the rule of external recognition. ${ }^{2}$ In this chapter, I generalize the concept.

Tertiary rules are an element necessary for the development of a concept of laws instead of law. The argument for a concept of laws rests on the conviction that a proper understanding of global law is neither monist or pluralist but instead must transcend the difference between monism and pluralism. That global law is differentiated into distinct legal systems, which interrelate and organize their interrelations through tertiary rules. Such tertiary rules therefore presume that legal systems are at least partly autonomous from each other, but at the same time they also make such partial autonomy possible.

The argument rests on a number of assumptions. These assumptions are not self-evident and will require justification at some point, but here is not the right place to demonstrate why they are justifiable, and so I ask the reader to accept them, for the purpose of this argument, as given.

The first assumption is that global law is both one and many at the same time. ${ }^{3}$ Global law is many in the sense that we have many separate legal orders, state and non-state, and we do not have a comprehensive meta-law that brings them all together. Global law is one in the sense that none of the many separate legal orders really exists in isolation from the other: they interrelate with each other, and none of them can be fully

${ }^{2}$ R. Michaels, 'Law and Recognition: Towards a Relational Concept of Law', in N. Roughan and A. Halpin (eds), In Pursuit of Pluralist Jurisprudence (Cambridge University Press, 2017), pp. 90-115. Some of the material in this chapter draws on that earlier chapter.

3 Ibid; see also T. E. Riesthuis, 'The Intertwinement of Legal Orders - A Critical Reconstruction of Theories of Jurisprudence' $\mathrm{PhD}$ Thesis, Erasmus University Rotterdam (2019). 
explained without regard to the other. In this sense, entanglement is a universal condition of law. ${ }^{4}$ If this is so, then legal theory must change from a concept of law to a concept of laws, from a concept of law as essentially one to a concept of law as one and many at the same time. For this concept of laws, traditional legal theories, whether monist or dualist, are useful but insufficient.

The second assumption is that legal systems are separate from each other. This has become a minority position within pluralist theories of global law. Such theories often emphasize that borders between alleged systems are blurred, or that transnational law does not allow for such borders altogether. ${ }^{5}$ In fact, there is a fascination with hybrid spaces that transcend borders. This is not the place to demonstrate comprehensively the assumption of this chapter in favour of separate legal systems, but two remarks may be helpful. First, the observation that borders are transcended is often a sociological and not a legal observation. As such it is important but not novel: it is a core insight of empirical legal pluralism that legal rules of different origins not only overlap but are also frequently mixed. But such sociological observations are of limited use for a legal theory that looks at the operation of legal rules. Second, the assumption is not that legal systems are natural entities to which the law only responds. In fact, the separatedness of legal systems is in no small part itself a creation of law, and most importantly by tertiary rules. Tertiary rules thus do not only respond to, and organize, a world of separated legal systems, they are themselves involved in the creation of such a system.

This last argument has already alluded to the third assumption, namely that entanglement between legal orders is organized by law. ${ }^{6}$ Law organizes its own plurality through its own rationality: it is inadequate and incomplete to describe entanglement solely in extra-legal ways (just as it would be inadequate and incomplete to describe, for example, contractual relations solely in extra-legal ways). In this sense, the theory is a positivist theory: it assumes that not only the definition and the creation of law but also the way in which legal orders relate to

${ }^{4}$ I take it that this is what Nico Krisch has in mind with the concept of entanglements: see Chapter 1, Section 1.1.

${ }^{5}$ In this context, Nico Krisch, in Chapter 1, speaks of 'straddling norms' or 'straddling practices'.

${ }^{6}$ See also Section 16.4.2. 
each other are themselves operations by the legal system. ${ }^{7}$ To this extent, the concept of laws is autopoietic. However, in emphasizing that legal systems mutually constitute each other, the concept also includes an allopoietic aspect. While the law at large is autopoietic, individual legal systems are not; they constitute each other through mutual recognition. There may, of course, be other theories of law to describe legal entanglement, and it may even be the case that a positivist theory does not explain all aspects of entanglement - though it seems that positivist approaches to global law, which had fallen somewhat out of fashion, are becoming more defensible in recent times. ${ }^{8}$ But, I would argue, any theory that is entirely non-positivist - that is, a theory that does not account for the fact that entanglement is organized in legal ways - is necessarily incomplete.

The fourth assumption is that this ordering takes place in a heterarchical way. This is the kind of ordering that presents the greatest challenge to legal theory. Where entanglement takes place between legal orders that are in a clear hierarchical relation, entanglement is relatively simple, because it is simply organized by the hierarchically superior order. ${ }^{9}$ However, in many cases, entanglement takes place between legal orders none of which is clearly hierarchically superior to the other and therefore able to determine, with binding force for the other, how the entanglement is organized. It is in these heterarchical situations where we must understand and explain the way entanglement is organized.

${ }^{7}$ Legal positivism is here meant in the sense of normative positivism: the bindingness and legitimacy of legal rules depends on legal, not extra-legal criteria. (See, e.g., J.-R. Sieckmann, Rechtsphilosophie (Mohr Siebeck, 2018), pp. 14-15.) This definition is different from the one in F. Schauer, 'Normative Legal Positivism', in P. Mindus and T. Spaak (eds), Cambridge Companion to Legal Positivism (Cambridge University Press, 2021), pp. 61-78. It is not meant in the sense of sociological positivism: that legality is an observable social fact. In this sense, it follows Kelsen rather than Hart. For a forceful argument in favour of Kelsen's basic norm over Hart's rule of recognition for problems of cross-border normativity, see D. Dyzenhaus, 'The Janus-Faced Constitution', in J. Bomhoff, D. Dyzenhaus and T. Poole (eds), The Double-Facing Constitution (Cambridge University Press, 2020), pp. 17-53, p. 17.

${ }^{8}$ See, e.g., J. Kammerhofer and J. d'Aspremont (eds), International Legal Positivism in a Post-modern World (Cambridge University Press, 2014); L. Siliquini-Cinelli (ed.), Legal Positivism in a Global and Transnational Age (Springer 2019).

9 See also Section 16.4.3. 


\subsection{Cross-Border Normativity}

\subsubsection{Primary and Secondary Rules within One Order}

Because tertiary rules obviously present themselves as an addition to the idea of primary and secondary rules, it makes sense to describe first why the Hartian system of primary and secondary rules is incomplete. ${ }^{10}$ Hart's own introduction of a distinction between primary and secondary rules, introduced in his Concept of Law in 1961, came in response to a perceived shortcoming of legal positivism at the time. As conceived by John Austin, legal positivism reduced the law to a system of commands. The problem with such a definition was its inability to differentiate between legal and other commands. Why was the order by a sheriff to hand out one's assets a legal command, but the similar order of a mugger was not? How, in short, should one distinguish legal rules from non-legal threats?

Hart's answer borrowed from the dual concept of internal and external sovereignty: 'The legal system of a modern state is characterized by a certain kind of supremacy within its territory and independence of other systems. ${ }^{11}$ He went on to find an ingenious explanation for the first of these aspects, that of supremacy, but not for the second.

For rules to count as law, Hart suggested, they have to emerge from a source recognized as competent to do so. The rule that determines who can competently set laws is the so-called rule of recognition - not a legal rule but a sociological fact for Hart, though others have suggested that the rule of recognition is better understood as a legal rule. The recognition of who is entitled to make laws does not yet, on its own, determine the conditions under which that person's orders actually are valid law. The determination of this is done by an additional set of rules that Hart calls secondary rules. Some of these rules determine who can make laws, some of these rules determine through what processes laws are made, some of these rules determine institutions and procedures of adjudication.

${ }^{10}$ My argument thus draws on Hart here in part for terminiological reasons, although it might actually fit better with a Kelsenian conception of validity. See Dyzenhaus, 'The Janus-Faced Constitution'.

11 H. L. A. Hart, The Concept of Law, 3rd ed. (Oxford University Press, 2012), p. 24 (emphases in original). On internal and external sovereignty, see, e.g., S. Krasner, 'Sovereignty', in G. Ritzer (ed.), The Blackwell Encyclopedia of Sociology (WileyBlackwell, 2007). 
The introduction of secondary rules created a significant advance for legal positivism. It was now possible to explain normativity without having to resort to natural law foundations for the law. The distinction between primary and secondary rules made it possible to distinguish between the effectiveness of a rule - that had essentially been Austin's only concern - and its validity and applicability. Legal rules as opposed to mere commands were now those rules that actually had legal validity because they were made by recognized officials in the ways provided for by the law. Moreover, they were those rules that were not only followed by ordinary citizens (out of concern over the threat that backed them up) but also were those rules applied by officials asked to apply or enforce the law. In addition, the separation between effectiveness on the one hand, validity and applicability on the other, also enabled the construction of law as a system, or at least an order. Commands backed by threats can come in isolation. Primary rules created and validated through secondary rules, by contrast, become part of a bigger whole: they relate to each other. Where primary rules are in apparent conflict, secondary rules are able to resolve that conflict, though whether they succeed may depend on an additional account for law's systematicity, either a juridical one (like Kelsen's idea of law as a system) or an extra-legal one (like Dworkin's idea of law as integrity). ${ }^{12}$

\subsubsection{The Challenge from Cross-Border Normativity}

Helpful as it is for internal sovereignty, ${ }^{13}$ the introduction of secondary rules does not help for external sovereignty. Here, Hart had little to offer. Granted, external sovereignty itself - the fact that foreign rules could not, on their own, bind subjects in England - is no problem for his theory. The challenge for jurisprudence emerges from the plurality of laws, but if plurality were all there is to it that challenge would not be very great. What is challenging, and insufficiently conceptualized in jurisprudence, is the relation and interaction between laws - the problem of crossborder normativity. In his Concept of Law, Hart dealt with the challenge through a (somewhat simplistic) idea of replication: in his view, the Russian law that an English court may apply is really not Russian law

12 On potential parallels between Kelsen and Dworkin here, see Dyzenhaus, 'The JanusFaced Constitution', 41-2.

13 P. Eleftheriadis, 'Law and Sovereignty' (2010) 29 Law \& Philosophy 535-69. 
but English law modelled after Russian law. ${ }^{14}$ Later, in a debate with Hans Kelsen, he rejected Kelsen's monist theory of a unity of all laws and even began conceptualizing types of relations between laws: completion, reception and delegation. ${ }^{15}$ Nonetheless, his statement that 'there is a good deal of unfinished business for analytical jurisprudence still to tackle ${ }^{, 16}$ seemed true then and still seems true today, despite a growing and important body of scholarship tackling these questions.

Cross-border normativity describes the situation that legal rules from system A somehow have normative force within and for system B. Crossborder normativity plays a role in a number of contexts. The conflict of laws provides the best, though by far not only, example for this. Whether a marriage celebrated by two Syrians in Syria is considered valid in Germany is, with some exceptions, determined by Syrian, not German, substantive law. Article 13 of the German Introductory Act explicitly says as much: the substantive validity of a marriage is governed by the law of the parties' nationality. Syrian law, therefore, becomes in some ways part of German law - it will govern the relation of parties living in Germany, and it will be the applicable law for judges. But it remains Syrian law.

\subsection{Three Strategies for Cross-Normativity}

Such cross-normativity is difficult for legal theory to conceptualize. In this section, I look at three types of responses to the problem, hoping to cover a wide array of existing responses without having to address, or even name, each individual response. A first set of attempts denies that foreign law is law. A second set of attempts denies that foreign law is foreign. A third set of attempts, finally, denies the interrelation of laws. ${ }^{17}$

14 This is similar to the so-called local law theory in private international law; see Section 16.3.2.

${ }^{15}$ H. L. A. Hart, 'Kelsen's Doctrine of the Unity of Law', in H. L. A. Hart, Essays in Jurisprudence and Philosophy (Oxford University Press, 1983), pp. 309-42. Cf. D. von Daniels, The Concept of Law from a Transnational Perspective (Ashgate, 2010), pp. 158-60.

16 See Hart, 'Kelsen's Doctrine', 310.

${ }^{17}$ In an earlier publication I distinguished three modes of responding to foreign law outside of its recognition at law, namely incorporation, deference and delegation. See R. Michaels, 'The Re-State-Ment of Non-state Law: The State, Choice of Law, and the Challenge from Global Legal Pluralism' (2005) 51 Wayne Law Review 1209-59, at 1231ff. The three modes correlate with the three positions discussed in Sections 16.3.1-16.3.3 - deference denies normativity, incorporation denies (or overcomes) foreignness, delegation establishes hierarchy. 


\subsubsection{Denying Normativity}

A first way to deal with foreign normativity is simply to deny its normative nature: to treat foreign normativity as fact. We used to find such approaches quite frequently in legal doctrine. They emerged from a concern about foreign normativity. But the responses proved to be neither convincing conceptually nor to lead to adequate normative results.

A first example is the fact doctrine in civil procedure. The doctrine emerges from English law, where the only law that could be applied was domestic law, and so foreign law had to enter the courts not as law but as fact. ${ }^{18}$ This has implications in particular for the procedural treatment of foreign law - under the doctrine, its validity and content must be proven like that of any other law, and burdens of evidence can be allocated according to who relies on the foreign law. The fact doctrine is not entirely wrong: foreign law (like domestic law) is, of course, also a fact. ${ }^{19}$ But the doctrine cannot explain the normative force that foreign law has in domestic courts - that it is applied as law, not merely referred to as fact. Insofar as claims and defences are based on foreign law, it seems impossible to deny that the foreign law has its own normativity within domestic courts, and thus differs from facts. Indeed, the procedural treatment of foreign law as fact demonstrates this (and is another reason for the doctrine's decline) ${ }^{20}$

A second example emerges from choice of law, in particular within an approach popular for some time in England and the United States and in a different way in France: the vested rights theory. ${ }^{21}$ Under this theory, the applicable law in English courts is still only English law. But foreign law can enter English courts in the form of rights that parties have acquired abroad under foreign law and are now having enforced. This seemed a clever trick to justify normativity while denying that an English judge would actually apply foreign law, but it was an unsuccessful trick. The main problem of the theory had already been shown by Wächter in

18 R. Fentiman, Foreign Law in English Courts: Pleading, Proof and Choice of Law (Oxford University Press, 1998).

19 See N. Jansen and R. Michaels, 'Die Auslegung und Fortbildung ausländischen Rechts' (Interpreting and Developing Foreign Law) (2003) 116 Zeitschrift für Zivilprozess 3-55.

${ }^{20}$ Comparatively, see Y. Nishitani, 'General Report', in Y. Nishitani (ed.), Treatment of Foreign Law: Dynamics towards Convergence? (Springer, 2017), pp. 3-60, at pp. 18-19.

${ }^{21}$ See R. Michaels, 'EU Law as Private International Law? Reconceptualising the Countryof-Origin Principle as Vested Rights Theory' (2006) 2 Journal of Private International Law 195-242. 
the nineteenth century: it is impossible to say that a right is 'vested' under foreign law unless we determine previously that the law under which it 'vested' is actually applicable. ${ }^{22}$

It is worth noting that the vested rights theory continues to have a (limited) existence in the enforcement of foreign judgements. Previously, foreign judgements were not actually enforced but merely treated as (irrebuttable) evidence for the existence of a claim that was then enforced under the forum's own law - they were, in other words, treated as facts. Even today, foreign judgements are, in principle, enforceable without a reference to the foreign law on which they may be based.

\subsubsection{Internalization of Normativity}

If these theories denied, unsuccessfully, the lawness of foreign law, other theories attempt to deny the foreignness of foreign law. One way to do so is through incorporation - turning the foreign rule into a domestic rule. Short of actual colonization of a foreign country, such incorporation will, however, rarely be complete. ${ }^{23}$ The legal rule will remain foreign. It would be odd to say that rules of Soviet law become rules of English law merely because a judge applies them. ${ }^{24}$

Hart's replication theory provides an alternative explanation: in reality, he says, English law replicates a rule of Soviet law. It finds its equivalent in the so-called local law theory in private international law. ${ }^{25}$ According to this theory, an Italian judge, when asked to apply English law, never really applies English law. What she does apply is a rule of Italian law that is modelled after English law. Here, the legal character of English law is accepted, but its normativity is derived from its character as a rule of Italian law. The doctrine has not been convincing either.

Cavers formulated the most compelling criticism: $^{26}$

${ }^{22}$ The relevant passage is translated in K. H. Nadelmann, 'Some Historical Notes on the Doctrinal Sources of American Conflicts Law', in K. H. Nadelmann, Conflict of Laws: International and Interstate. Selected Essays (Nijhoff, 1972), pp. 1-20, at p. 16.

${ }^{23}$ See J. Raz, 'Incorporation by Law' (2004) 10 Legal Theory 1-17.

${ }^{24}$ Ibid., 10.

25 W. W. Cook, 'The Logical and Legal Bases of the Conflict of Laws' (1924) 33 Yale Law Journal 457-88; R. De Novo, 'New Trends in Italian Private International Law' (1963) 28 Law \& Contemporary Problems 808-21, at 812-13.

26 D. F. Cavers, 'The Two "Local Law” Theories' (1950) 63 Harvard Law Review 822-32, at 823. See also Dyzenhaus, 'The Janus-Faced Constitution', 31-2. 
Theories that explain how it is that a foreign rule isn't foreign law when it is used in deciding a case in another country might seem more useful if I could forget the way in which my son resolved a like problem when, at the age of four, he encountered tuna fish salad. 'Isn't that chicken?' he inquired after the first bite. Told that no, indeed, it was fish, he restored his world to order and concluded the matter by remarking to himself, 'Fish made of chicken'.

Cavers' son seems right. When a judge has to apply foreign law, she must, to a great extent, attempt to apply that law in the way in which it is applied abroad. What is demanded from her, therefore, is the actual application of a foreign law. Replication is a cumbersome fiction, made necessary only if we assume that cross-boundary normativity is not possible. These shortcomings are consequences from Hart's thinking within one legal system, namely his own. ${ }^{27}$

\subsubsection{Sharing of Authority}

A third attempt to deal with cross-normativity exists in the literature on legal pluralism. Much of this literature does not conceptualize interactions between overlapping orders, beyond stating that they exist, but some does. A jurisprudentially ambitious attempt is what Nicole Roughan calls 'relative authority', by which she means 'shared or independently held normative power'. ${ }^{28}$ Roughan recognizes, based on ideas from legal pluralism, that multiple legal orders may not only coexist but even claim normative force with regard to the same situation - a conflictof-laws situation, if you will. In response, she suggests that multiple laws (or institutions) may share authority: they may, each, cover only part of the normative space. The prerequisite for this is a justified interauthority relationship' between the different orders. Conflicts between such orders may be resolved by 'meeting in the middle' - effectively, the drawing of compromise. ${ }^{29}$

From an external perspective, such an idea of shared authority appears attractive. For a strictly positivist theory, by contrast, it runs into three problems. The first is that legal orders are not usually incomplete in the

27 On Hart's 'parochialism' see D. Dyzenhaus, 'Kelsen's Contribution to Contemporary Philosophy of International Law' (2020), https://ssrn.com/abstract=3571343.

28 N. Roughan, Authorities: Conflicts, Cooperation, and Transnational Legal Theory (Oxford University Press, 2013), pp. 136 et seq.

${ }^{29}$ N. Roughan, 'Meet Me in the Middle?' (2019) 29 Duke Journal of Comparative \& International Law 423-36. 
sense that they deliberately limit themselves without need. The English law on negligence is, potentially, universal. Granted, there are cases in which an English court will not apply that law, for example with regard to a tort committed in France, and in that sense there is a sharing of authority. But this is in consequence of (real or potential) conflicts, not intrinsic to English law itself.

This first problem may seem banal on its own, but it is exacerbated by a second one. Roughan calls her mechanism of cross-border authority a 'justified inter-authority relationship', but while she develops criteria for that justification, she does not say where the normative foundation of the justification derives from. The justification does not appear to come from one of the two authorities, but where does it rest instead? Morality? Natural law? Practical reasoning? None of these justifications is available to a positivist theory of law. And none of them seems to account for the way in which each legal order in fact mediates its relation to others.

A third problem concerns the border between the authorities: who determines it, and how? Roughan proposes that conflicting authorities should compromise, 'meet in the middle'. This sounds like an attractive solution, the likely result of a (real or hypothetical) agreement between the orders. But such difference-splitting is problematic. ${ }^{30}$ Where exactly is that middle? Why should we think legal orders agree on the middle, rather than on any other point of the continuum between full authority for one or the other legal order? And how do we account for a situation in which the authorities actually do not agree where the middle is? Must we defer analysis until such agreement occurs or one authority 'wins'?

\subsection{The Answer of Tertiary Rules}

It is proposed that a better way to account for relations between legal orders is the concept of tertiary rules. Tertiary rules share characteristics with secondary rules insofar as they do not constitute commands; instead, they serve to identify the processes by which the applicable commands can be recognized. This is why several scholars, beginning with Hart himself, have viewed them as extensions of secondary rules. ${ }^{31}$ They differ from secondary rules in one significant way however: they

30 See D. Kennedy, 'Strategizing Strategic Behavior in Legal Interpretation' (1996) Utah Law Review 785-825, at 795-6, 808-9.

31 J. P. Trachtman, The Future of International Law: Global Government (Cambridge University Press, 2013), p. 272; T. Schultz, 'Secondary Rules of Recognition and 
determine the scope of foreign, not domestic, law. Ignoring this crucial difference leads to significant and consequential misunderstandings.

I am not the first to propose such a concept - my tertiary rules share certain characteristics with Nico Krisch's interface norms and with Detlef von Daniels' linkage rules. ${ }^{32}$ Even the term tertiary rules has been used before: Joel Trachtman has used it to account for rules that 'allocate authority among constitutions: among state constitutions, between state constitutions and international organization constitutions, and among international organization constitutions'. ${ }^{33}$ But the concept is not yet, I think, sufficiently precise. In the following I try to develop a precise concept of tertiary rules, and discuss in what ways it differs from the other projects mentioned.

A definition of tertiary rules is not easier than a definition of secondary rules, but here is an attempt: Tertiary rules are rules with which one legal order designates, relative to itself, the normative space of another legal order to which it is not hierarchically superior. This definition requires explanation, which takes place here. Perhaps more importantly, it requires application and examples, which will take place in Section 16.5 , where three different types of tertiary rules are explicated at somewhat greater length.

\subsubsection{Designation of Normative Spaces}

A first element of this definition that requires explanation is the rather amorphous term normative spaces. Why not rather the validity or bindingness of foreign rules? After all, the question for a positivist theory of law (or laws) in the Hartian tradition is to determine what does and what does not count as normatively valid.

Relative Legality in Transnational Regimes' (2011) 56 American Journal of Jurisprudence 59-88.

${ }^{32}$ N. Krisch, Beyond Constitutionalism: The Pluralist Structure of Postnational Law (Oxford University Press, 2010), pp. 285-96; von Daniels, The Concept of Law from a Transnational Perspective, pp. 158-66.

33 Trachtman, The Future of International Law, p. 272, see also pp. 286-87. For an earlier version of the argument, see J. P. Trachtman, 'The Constitutions of the WTO' (2006) 17 European Journal of International Law 623-46, at 627. Trachtman does not, however, provide a more extensive analysis of either the nature or the scope of tertiary rules, except to link the concept to an idea of global law as both one and plural. As a consequence, neither the legal character nor the origin of these tertiary rules becomes clear. A different concept of tertiary rules can be found in J. Hampton, 'Democracy and the Rule of Law' (1994) 36 Nomos 13-44, at 35-36: rules about changing secondary rules. 
Tertiary rules do indeed give normative validity to (foreign) legal rules, but that alone does not distinguish them from secondary rules, and that similarity does not account for existing differences. The difference is this: secondary rules operate within one legal order - they give validity to rules that would otherwise have no validity at all. A legislative bill that does not obtain the required parliamentary majority does not become a valid legal rule at all. In the transnational realm, unlike in the domestic realm, we are confronted not only with the relations between legal rules within one system. We are additionally confronted with the limitations and crossreferences existing between, not within legal orders. In response, tertiary rules operate between legal orders: they extend the validity that a rule in a foreign legal order already has into another legal order where it does not have that validity.

This focus on foreign normativity distinguishes tertiary rules from a whole number of techniques that respond to the existence of competing normativities through self-restraint. The presumption against extraterritoriality is one of many examples. According to this doctrine, courts should choose an interpretation of statutes that confines its scope of application to the home state's own territory. Such techniques are not tertiary rules, however. They determine the scope of application of a legal order's own rules and are, as such, secondary rules, insofar as they are directed at adjudicators or other norm interpreters. The restriction of a rule's scope of application is an ordinary process within domestic law; it does not change its nature when it happens in response to normative claims from another legal order any more than it does when it happens in response to other normative claims. Tertiary rules do something different: they provide normative space to foreign legal rules.

Unlike secondary norms, tertiary rules do not provide requirements for the change of rules and institutions of foreign orders, nor do they provide specific rules on adjudication. The courts and rules of legal order B never derive their validity exclusively from legal order A. Instead, tertiary norms deal with the recognition and application of foreign institutions and rules that are already valid under foreign law. Rules of Syrian marriage law are valid, within Syrian law, regardless of whether they are designated by a German conflicts rule or not. This is why it would be misleading to say that tertiary rules allocate authority. The German conflicts rule does not create the validity of the rule per se; all it does is extend that validity and bindingness into German law. The question for tertiary rules is not whether a law is binding or valid in the abstract - that 
is, in principle, determined by the legal order to which the law belongs but to what extent it has normative force in the concrete case in the view of another legal order. This means, firstly, that the issue of normative space includes not only validity and normativity but also their respective space and limitations. The normative space granted to legal order B by legal order A may be narrower than that which legal order B grants to itself. It means, in addition, that what matters are not only questions of validity and general bindingness but also of applicability.

\subsubsection{Legal Nature}

Second, in accordance with the positivist aim of this approach, I understand tertiary rules as legal rules. The designation of normative spaces is an operation of law, and tertiary rules are part of the legal system of A. This means that choice-of-law rules are tertiary rules, as are rules on the recognition of foreign judgements. By contrast, diplomatic negotiations are not, ${ }^{34}$ nor are ideas about inter-institutional dialogue, compromise and so on and so forth. Such processes have an existence of course, and they are also often legitimate, though not unsuspicious. ${ }^{35}$ But they have no space within a positivistic theory of law that aims at determining normativity, not factual actions that are taken.

I can see two objections to this postulate. The first is that it would be unduly restrictive to exclude non-legal mechanisms. Functionally, legal and non-legal mechanisms both operate towards similar ends. Indeed, some mechanisms are not easily placed within one or the other category. Comity, for example, is often placed somewhere between law and politics - 'neither a matter of absolute obligation, on the one hand, nor of mere courtesy and good will, upon the other', to use the US Supreme Court's famous definition. ${ }^{36}$ But what matters here is not function but mode. There are many ways in which legal claims can be negotiated between legal orders, just as there are many ways, legal and non-legal, to

34 This does not deny that certain moves of diplomacy can be reconceptualized as conflictof-laws moves: K. Knop and A. Riles, 'Space, Time and Historical Injustice: A Feminist Conflict-of-Laws Approach to the "Comfort Women" Settlement' (2016) 102 Cornell Law Review 853-928, at 885ff.

${ }^{35}$ See K. Knop, R. Michaels and A. Riles, 'From Multiculturalism to Technique: Feminism, Culture, and the Conflict of Laws Style' (2012) 64 Stanford Law Review 589-656, at 648-52.

${ }^{36}$ Hilton v. Guyot, 159 U.S. 113, 143 (1895). 
resolve disputes. But we call only some of these ways legal, and they are distinct through their mode.

This leads to the second, more fundamental, possible objection. Maybe it is wrong to refer to any techniques of cross-boundary normativity as legal. It is now widely accepted that public international law is law. But maybe private international law is not. ${ }^{37}$ Or, put more generally (and plausibly), the legal rules of private international law are not really different from secondary rules within a system, whereas the relation between legal orders, that is, cross-boundary normativity, is in reality regulated through extra-legal norms.

This would be a category error. It may of course be possible to describe tertiary rules as mere social practices. It is also possible to describe, in quasi-realist fashion, what factors courts actually use in order to resolve conflict-of-laws issues, perhaps regardless of the existing doctrine. Notably, however, that would not distinguish tertiary rules from other rules. For Hart, the rule of recognition was a social, not a legal rule. Andrei Marmor argues that all secondary rules are social and not legal rules: they describe the practice of legal officials in determining what should and what should not count as law. ${ }^{38}$ Scandinavian legal realism explains even primary rules as social facts, not legal rules. But such attempts could not account for the particular mode in which such decisions are justified, namely through invocation of legal rules and techniques. A description of choice-of-law reasoning as the mere following of a certain social norm cannot account for the complexity in which this reasoning occurs, the complexity of legal technique. Non-legal modes of negotiating between legal orders - diplomacy, for example - may at times also be complex. But their complexity is of a very different kind.

\subsubsection{Horizontal Nature}

So far, tertiary rules are not significantly different from secondary rules. What sets them apart, what is in fact their most important characteristic, is their horizontal nature. Tertiary rules are part of one legal order that is not hierarchically superior to the legal order whose normative space is

37 See R. Michaels, 'Post-critical Private International Law: From Politics to Technique', in H. Muir Watt and D. P. Fernández Arroyo (eds), Private International Law and Global Governance (Oxford University Press, 2014), pp. 54-69, at pp. 54, 57-8.

38 A. Marmor, Positive Law and Objective Values (Oxford University Press, 2001). 
designated. If English law designates the normative space of Moroccan law, it does so in a horizontal way. English law is not superior to Moroccan law, and yet designates the latter's normative space.

It is useful, first, to distinguish tertiary rules from two other types of rules that are not horizontal in nature. The first of these are vertical priority rules based on hierarchy within one legal system. The supremacy clause of the US Constitution, for example, creates, within the US legal system, a hierarchy between federal and state law. In this hierarchy, state law is valid only insofar as it does not exceed the normative space of the laws of the individual states (they are valid insofar they do not contradict federal law). Within the system of US law, the supremacy clause is a secondary rule, just like a rule that designates the later-in-time rule to trump the former-in-time, or the special rule to trump the general rule.

The other type are rules that exist in a legal system that is hierarchically superior to both legal orders between which it mediates. In this sense, public international law allocates jurisdictional authority among states. And in this sense, EU private international law rules allocate authority between the laws of France and Germany. These EU rules are choice-oflaw rules, but although the relation between the laws of France and Germany may be horizontal, the relation between EU law and these two legal orders is not.

In several ways vertical priority rules look like tertiary rules: they designate normative spaces, and they act inter-systemically. However, they do not operate in a horizontal way, and this makes the difference. A tertiary hierarchy rule is uniform for all affected legal systems. By contrast, and this is crucial, tertiary rules are not uniform for all affected legal system. Instead, each legal system has its own tertiary rules, and because there is no hierarchy between the affected legal systems, all of them coexist. English law has rules designating the normative space of rules from Moroccan law, just as Moroccan law has rules designating the normative space of rules from English law.

As a consequence, tertiary rules are reciprocal. However, these rules are not necessarily symmetrical. The way in which English law designates the normative space of Moroccan law is independent from the way in which Moroccan law designates normative space for English law. A fortiori, the normative space given to Moroccan law by English law may be different from the normative space given to English law by Moroccan law. 
It follows that there is not one but two borders between English law and Moroccan law. ${ }^{39}$ Or, put differently, the resulting border may look different from the perspective of each system. As a consequence, a certain set of facts may be within the limits of English law from the perspective of English law, and within the limits of Moroccan law from the perspective of Moroccan law (a situation private international lawyers call a true conflict). Or, conversely, it may be within the limits of Moroccan law from the perspective of English law, and within the limits of English law from the perspective of Moroccan law (a situation that private international lawyers call renvoi). ${ }^{40}$

Often, there will be such symmetry, or at least mutuality, and agreement on the place of the border. Often, English law will only be willing to grant normative space to Moroccan law if and insofar as Moroccan law grants such normative space to English law in other cases. In this sense, reciprocity is often viewed as the foundation of international relations and, by extension, international law. But this is only a special case, and by far not uniformly true. Tertiary rules, as explained here, are rules of each domestic law, not of international law. Whereas reciprocity and mutual respect provide good reasons for having such rules, they are neither necessary for such rules to exist, nor are they sufficient in bringing such rules about.

\subsubsection{Relationality}

All of this brings about the possibility that conflicts - or, put more neutrally, disagreements about the place of the border between legal systems - may exist. Such conflicts are a problem of theories of law that are not plural in nature. One legal system cannot be a system, arguably, if it does not provide mechanisms with which conflicts are resolved. Indeed, most legal systems provide secondary rules to resolve such conflicts if they occur within one system. Tertiary rules make it possible to account for the fact that, as between legal systems, conflicts can continue to exist. Thus, it may be possible that a certain conduct is

39 See R. Michaels, 'A Symmetry of Asymmetries? A Private-International-Law Reconstruction of Lindahl's Work on Boundaries' (2019) 29 Duke Journal of Comparative and International Law 405-22, at 419.

${ }^{40}$ Cf. H. Kelsen, 'Observations' (1957) 447 Annuaire de l'Institut de droit international, II, 115; republished in C. Leben (ed.), Hans Kelsen - Écrits français de droit international (PUF, 2001), p. 309. 
governed by English law from the perspective of English law, and at the same time governed by Moroccan law from the perspective of Moroccan law. This means, however, that there no longer is an independent position from which to determine whether some rules do or do not count as valid and applicable law. Instead, there are separate legal systems, each of which determines what counts as law for itself (through a rule of internal recognition) and for other orders (through a rule of external recognition). The normative space of each legal system differs depending on the legal system from which it is designated.

The biggest challenge then from tertiary rules - the main reason why they are so hard to conceptualize from the perspective of traditional legal theory - is their relationality. ${ }^{41}$ What is meant by relationality is this: the tertiary rules of English law designate normative spaces of foreign laws only relative to English law itself. English law cannot designate the normative space of Moroccan law with binding force for any order other than English law. It can certainly not bind Moroccan law: if a rule of Moroccan law is held to be inapplicable by a court in London, this does not mean that it is inapplicable from the perspective of Moroccan law. Nor can English law bind a third legal system, for example Japanese law with regard to Japan's own designation of the normative space of Moroccan law. If a rule of Moroccan law is held to be inapplicable by a court in London, Japan remains free to hold the rule applicable in relation to Japan.

On the flipside, a legal order cannot designate its own normative space with binding force for any other legal order. Certainly, it would be unusual for a court in Morocco to consider a rule of English law applicable even though an English court would not apply it. But it would be perfectly possible. For example, take a case in which Moroccan law designates the law of nationality to be the applicable law, whereas English law designates the law of the domicile to be applicable. In that case, arguably, Moroccan law would limit the normative space of its own legal order so that it would not include an Englishman domiciled in Morocco. Nonetheless, an English court would be free to apply Moroccan law to this person regardless. ${ }^{42}$

This relationality and relativity of a concept of law are necessary consequences of global legal pluralism. We no longer have an Archimedean point from which we can determine whether something

41 See already Michaels, 'Law and Recognition'.

42 The English court would indeed do so, provided it did not apply the doctrine of renvoi. 
is or is not law. If we accept that the definition of law is itself the fruit of the operation of legal rules, then we have to find these rules in the law. And if laws are interrelated, then we can find these rules not merely within each legal system, but must instead look within other legal systems, too. Because such rules operate between legal systems only, they lead to a relational concept of law. The nature of law, the normative space of law, is no longer determined in an absolute fashion but only relative to other legal systems. Something can be a legal order vis-à-vis one other legal system, but not vis-à-vis another legal system. The nature of a legal system exists in relation to another legal system. The normative space of a legal system in the world is determined, in part, by other legal systems.

\subsection{Examples of Tertiary Rules}

All of this has been quite abstract. Some examples will hopefully both demonstrate that tertiary rules actually exist and will clarify the abstract concept. That most of these come from the discipline of private international law should not be surprising: private international law is the discipline specifically focused on cross-border normativity. But no claim is made that all tertiary rules belong to private international law.

\subsubsection{External Recognition}

The first and arguably most important tertiary rule is the rule of external recognition. ${ }^{43}$ Under this rule, English law recognizes Moroccan law as a legal order. This means that legal order $\mathrm{A}$ is willing to designate a positive normative space to legal order $\mathrm{B}$, without yet determining how far this space extends. The clearest example exists in public international law: if the United Kingdom recognizes Palestine as a state, it thereby also expresses a willingness to recognize, as to an as of yet undefined extent, Palestine's laws as having a normative space. But external recognition goes to laws and legal orders, not to sovereignty. It can therefore in theory also designate normative space for non-state law.

The rule of external recognition exists in partial analogy to Hart's rule of recognition, but there are important differences. First, Hart's rule of recognition determines binding force of law within one system; I therefore call it a rule of internal recognition. The rule of external

43 This is discussed in more detail in Michaels, 'Law and Recognition'. 
recognition, by contrast, determines the binding force of another legal system. It is therefore properly called a rule of external recognition. That external recognition cannot be universal, as was seen before. An Italian judge can recognize Islamic law as law with effect only for Italian law, not in general. On the other side, the rule of internal recognition is also relative in this way, as Hart himself recognized. The rule of recognition of English law designates English law as binding (as law) only with force for the English.

Second, although both rules of internal and of external recognition create the possibility of normative spaces, they do so in different ways. The rule of internal recognition creates lawmaking power - without it, the recognized institutions would have no lawmaking power at all. The rule of external recognition, by contrast, does not create lawmaking power. The lawmaking power of a Palestinian legislator does not depend on recognition by English law. What does depend on that recognition is the normative space of resulting law, with regard to English law.

Third, whereas there is debate over whether the rule of internal recognition is a legal rule or a social fact, the rule of external recognition, as understood here, is undoubtedly a legal rule. The recognition of Moroccan law for English law is an operation of English law. That operation may of course be brought about by factual acts, like a declaration of recognition by a head of state. But that does not distinguish it from other operations: most legal operations are brought about by a factual act. If a pronouncement by the head of state of legal order A can bring about the potential bindingness of laws and decisions of legal order $\mathrm{B}$ for legal order $\mathrm{A}$, then this is not a social fact but a consequence of the rules of legal order $B$.

Fourth, whereas the rule of internal recognition is often discussed but rarely practically relevant, the rule of external recognition is actually important. The rule of internal recognition is largely irrelevant because the operation of legal orders depends largely on the self-reinforcing dayto-day operations of the law, based on the mutual and tacit, though rarely effectively expressed or doubted, assumption of a valid recognition. If, for example, some citizens in the southern states of the United States, or the so-called Reichsbürger in Germany, refuse to recognize the authority of their own governments, this is irrelevant not merely because they are unjustified in their refusal, but also (mainly) because their recognition is relatively unimportant. The rule of internal recognition is rarely questioned. By contrast, the recognition of foreign law as law is frequently relevant. This is not only the familiar question of illegitimate 
governments or of failed states, not even only that of non-recognized states, but also the question of the ability to make law more generally.

\subsubsection{Recognition of Foreign Acts, Records and Judicial Proceedings}

Just as Hart's rule of internal recognition alone is not sufficient for the functioning of a legal system, so the rule of external recognition alone is not sufficient to deal with cross-normativity as between normative orders. Another important set of tertiary rules concerns the recognition not of legal orders at large, but instead of individual products of other legal orders.

Such recognition is often required in federal systems. The US Constitution, in its Article IV Section 1 First Sentence, requires that 'Full Faith and Credit shall be given in each State to the public Acts, Records, and judicial Proceedings of every other State'. In a parallel way, EU law requires its member states to recognize a number of acts of other member states, so much so that one speaks of a principle of mutual recognition within EU law. ${ }^{44}$ These rules are not, however, tertiary rules in the sense in which I speak of them here. Their root is not decentralized within each legal order itself (see characteristic 1 in Section 16.4.1). They emerge from a superior system of law, which can, due to its (presumed) hierarchical superiority, allocate normative spaces with effect on all affected states alike. They are vertical hierarchy rules.

For tertiary rules, the validity of products of Moroccan law for English law is in principle dependent on two factors. The first is internal to Moroccan law and depends on Morocco's secondary rules: was the act produced by the appropriate authorities and within the proper competence? The second factor, however, is external to Moroccan law and depends instead on the tertiary rules of English law: does English law recognize the products of Moroccan law as valid?

Take, for example, my German passport that I present at the border entering the United States. The USA will not admit me to its territory unless my passport is valid. That validity is determined not by US law but by German law. It is true that the acceptance of my passport as valid

${ }^{44}$ See C. Jannsens, The Principle of Mutual Recognition in EU Law (Oxford University Press, 2013); K. Lenaerts, 'The Principle of Mutual Recognition in the Area of Freedom, Security and Justice', The Fourth Annual Sir Jeremy Lever Lecture (All Souls College, University of Oxford 2015), www.law.ox.ac.uk/sites/files/oxlaw/the_principle_of_ mutual_recognition_in_the_area_of_freedom_judge_lenaerts.pdf . 
under these conditions is a function of US law (in addition to international law, which I will ignore for purposes of the argument here). ${ }^{45}$ But it would be odd to claim that the United States, through its secondary rules, authorized the German authorities to create valid passports. The United States does have secondary rules for its own passports, which designate both the competent authorities to create passports and the processes through which this production takes place. It does not apply those rules to German passports, however.

The passport's validity under German law alone does not, however, make it binding on US authorities. Rather, whether the passport is recognized - and whether additional requirements must be met - is a function of a tertiary rule of US law. It is that rule that designates normative force to the passport vis-à-vis US authorities.

Documents may serve as the clearest example of recognition, but they are not the only one. Another example concerns the recognition of administrative acts. There is a question, for example, whether country A should, in regulating the conduct of corporation $\mathrm{X}$, take into account that corporation $\mathrm{X}$ received a permit for its conduct from country B. Under the principle of mutual recognition, there is a wide-ranging duty to recognize such permits, but that duty, as emerging from a hierarchically superior order, does not count as a tertiary rule. Such recognition is the object of tertiary rules, however, insofar it emerges from rules of the recognizing legal order itself.

Another example can be found in the recognition of foreign arrest warrants. Take the European arrest warrant. ${ }^{46}$ This warrant is issued not by a European authority but instead by one member state; it is, however, with few exceptions, recognized and enforced by other member states. Here, recognition does not go to a private privilege that an individual or a corporation wants to carry with them across boundaries, but instead expands the normative space of a foreign warrant beyond the territorial borders that would normally limit a sovereign's executive jurisdiction. Again, insofar as the duty emerges from EU law, it follows from a vertical

${ }^{45}$ International law obliges states to recognize foreign passports, but whether they do this remains a function of their own sovereign decision. For the interplay, see, R. A. C. Alton and J. R. Struble, 'The Nature of a Passport at the Intersection of Customary International Law and American Judicial Practice' (2010) 16 Annual Survey of International and Comparative Law 9-18.

${ }^{46}$ See V. Mitsilegas, 'Judicial Dialogue, Legal Pluralism and Mutual Trust in Europe's Area of Criminal Justice' (forthcoming) European Law Review. 
hierarchy rule. By contrast, if one country recognizes a foreign arrest warrant on its own, such recognition is a matter of a tertiary rule.

Finally, the recognition and enforcement of foreign civil and commercial judgements can count as an example for this type of tertiary rule. The old common law rule, by which judgements provided rights which, by themselves, the winning party could enforce anywhere, was incompatible not only with the idea of sovereignty but also with the justified interest of legal orders to refuse recognition and enforcement to judgements they considered incompatible with certain important values. By themselves, judgements bind only within the borders of the sovereign whose courts issued them. This is why a French seventeenth-century statute declared all foreign judgements to be without force in France, and why some countries still, technically, refuse to recognize and enforce foreign judgements outside of a treaty. In such systems, a foreign judgement can be considered as a fact, perhaps even, as in some theories, as irrefutable evidence of the existence of the underlying right. It can also be internalized into the enforcing legal order, as is the case in the technique of naturalization of foreign judgements. Modern theories (and practices) of judgement recognition follow neither of these twisted techniques, however. Instead, foreign judgements are recognized and enforced and thereby given normative space beyond their traditional borders.

\subsubsection{Application of Foreign Law}

The most important tertiary rules are, arguably, choice-of-law rules that designate the application of foreign law, mainly within the context of private international law. Foreign law is applied as a matter of course today, despite the considerable theoretical difficulty to explain such application within traditional legal theory. Indeed, the absence of private international law from most theories of law, including those of (public) international law and of private law, may be a consequence of such difficulties.

The misnomer 'choice of law', frequent in the common law world, is already a sign for these difficulties. The applicable law is not determined by a discretionary choice of the judge. Instead, the application of foreign law is an operation of the law itself, in this case the private international law rules of the forum. Save for a few exceptions, most prominently the conflict-of-laws regime of the European Union, these rules are not hierarchically superior. Instead, they are horizontal rules in the sense given above. 
Nonetheless, many explanations of private international law try to explain its rules by denying one of the criteria found here for tertiary rules. The vested rights theory as a theory denying normativity was already explained in Section 16.3.1. Another theory of private international law, the so-called datum theory, also denies foreign normativity and claims to consider foreign rules as mere facts (data). That approach has found a recent application in Article 17 of the Rome II Regulation, which mandates that 'account shall be taken, as a matter of fact and in so far as is appropriate, of the rules of safety and conduct which were in force at the place and time of the event giving rise to the liability'. The wording demonstrates the desire to avoid normativity, but it can hardly be denied that such 'taking into account' will often, effectively, amount to application. How else should such rules be taken into account if not in their normativity?

What choice-of-law rules do is to designate the normative space of law. An English rule that designates Moroccan law as applicable to a certain conduct thereby designates a normative space that Moroccan law would not otherwise have. Moroccan law might (or indeed might not) be applicable to the relevant facts relative to itself, that is, from the perspective of a Moroccan judge. But that normative space would not exist universally. An English private international law rule cannot make the space universal either. What it can do, however, is to designate a normative space relative to English law, that is, from the perspective of an English judge.

\subsection{Conclusion}

In this chapter I have argued that some rules that exist in legal systems cannot be understood as either primary or secondary rules but constitute a different type of rules, called tertiary rules. These are the rules with which a legal system organizes its own relation to other legal systems and also designates those other legal systems' normative space with regard to itself. Those rules have proven to be more complex than primary and secondary rules, and incompatible with certain postulates of traditional theories of legal systems that emphasize internal coherence and consistency. They are the consequence of a plural world in which law is not one but many.

Recognizing tertiary rules is thus necessary for a pluralistic theory of laws. However, the recognition of tertiary rules is not dependent on the recognition of such a theory. Tertiary rules are an actually observable 
category of rules within legal systems. This chapter does not invent them, it merely brings them together and describes their qualities. If anything, therefore, a pluralistic theory of laws is a necessary consequence of the recognition of tertiary rules which do not have a proper space in monist theories of law.

Regardless of such a theory, the concept of tertiary rules ought to be of both theoretical and practical interest. Theoretically, they represent an important category of rules and are instructive for the way in which such rules operate across borders. Practically, they help see commonalities between rules in different areas of law. And they help see differences from other rules, like rules of unilateral restraint, or from non-legal mechanisms to resolve normative conflicts. They thereby also provide ammunition against those who claim that conflicts of laws cannot be resolved except in extra-legal ways. The recognition of tertiary rules demonstrates that law is more varied and therefore more flexible that one may think on the basis of monist legal theories. 